\title{
Indoor Positioning System (IPS) Berdasarkan Kekuatan Received Signal Strength Indicator
}

\author{
Iffah El Masrura, Budi Rahmadya \\ Jurusan Sistem Komputer, Fakultas Teknologi Informasi, Universitas Andalas, Limau Manis, Pauh, Kota Padang, 25176, Indonesia
}

\section{ARTICLE INFORMATION}

Received: January 06, 18

Revised: March 03, 18

Available online: March 29, 18

\section{KEYWORDS}

Sistem monitoring, sistem keamanan, energi listrik, shopping mall, posisi, wi-fi, kekuatan sinyal, aplikasi mobile.

\begin{tabular}{l} 
CORRESPONDENCE \\
\hline E-mail: budi-r@fti.unand.ac.id
\end{tabular}

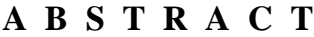

\begin{abstract}
Security in the Shopping Mall area is very important because of the many visitors. Monitoring system is needed as part of security to looking for someone which is applied to Shopping Mall area. The existing monitoring system only uses manual system that is by announcing the name of the visitors sought at the information center. This study aims to create a monitoring system used on the smartphone to determine the position of visitors without having to announce the name of the end sought in the information room. The monitoring system created is an application that uses Indoor Positioning System (IPS) where the user can find the position of the visitor sought using the smartphone through the Wi-Fi signal captured by the visitor's smartphone. This system uses QR Code which is used as user identifier (uid) from user in order to recognize user account. Visitor position is known by the system of the largest value of Wi-Fi signal strength caught by visitor's smartphone, so it will show the visitor's position on this app. This system has average percentage of success of overall system testing of $100 \%$.
\end{abstract}

\section{PENDAHULUAN}

Shopping Mall merupakan area pusat perbelanjaan yang besar dan memiliki sistem keamanan seperti sistem layanan informasi yang dapat dimanfaatkan oleh user untuk mendapatkan informasi yang dibutuhkan. Penggunaan sistem layanan informasi pada area Shopping Mall terkadang sangat tidak efektif. Hal ini dikarenakan user membutuhkan waktu yang lama dalam mendapatkan informasi, dimana user terlebih dahulu harus mencari lokasi tempat sistem layanan informasi tersebut. Hal ini menjadikan sistem keamanan pada Shopping Mall menjadi lemah. Kasus yang banyak dialami oleh user (pengunjung Shopping Mall), salah satunya adalah kasus salah seorang anggota yang terpisah dari rombongannya di area Shopping Mall.

Pada area Shopping Mall terjadinya kasus seorang anggota yang terpisah dari rombongannya merupakan kasus yang sering terjadi. Hal ini dapat disebabkan karena pengunjung dari Shopping Mall yang sangat banyak, sehingga terkadang ketua rombongan sangat sulit untuk mengkoordinasikan anggota rombongannya. Kasus seperti ini menambah kelemahan dari sistem keamanan yang dimiliki Shopping Mall. Hal ini disebabkan karena terkadang ketua rombongan tidak menyadari sejak kapan anggotanya terpisah dan dimana keberadaan anggotanya pada saat itu.

Pada penelitian sebelumnya telah dibahas tentang bagaimana memonitoring anak di ShoppingMall menggunakan teknologi RFID. Pada penelitian tersebut setiap anak yang masuk ke area Shopping Mall akan diberikan gelang yang telah ditanamkan RFID sebagai identitas dari gelang yang digunakan. Gelang yang digunakan terlebih dahulu telah didaftarkan pada sistem. Sehingga jika anak keluar dari area Shopping Mall dengan menggunakan gelang tersebut, maka sistem akan menerima pesan dan akan mengumumkan nama orang tua dari anak yang menggunakan gelang tersebut yang telah disimpan dalam database untuk dapat diambil tindakan selanjutnya[1]. Pada penilitian berikutnya telah dibuat aplikasi untuk menentukan posisi user dengan menampilkan peta dari gedung tersebut. Penelitian tersebut memanfaatkan sistem indoor localization dengan menggunakan sinyal Wi-Fi. Sedangkan kompas digital digunakan sebagai penentu arah menuju lokasi tujuan user[2]. 
Sistem keamanan pada area Shopping Mall yang banyak memiliki kelemahan, membutuhkan suatu pembaharuan. Terutama pada kasus tidak efektifnya user dalam mendapat informasi dari Shopping Mall dan kasus user (anggota dan ketua rombongan) yang saling terpisah. Indoor Positioning System (IPS) merupakan sistem yang dapat digunakan untuk mengetahui posisi user melalui kekuatan sinyal Wi-Fi yang didapat dalam gedung. Pada penelitian ini, penulis membuat suatu aplikasi android yang dapat digunakan untuk mengetahui posisi user pada area Shopping Mall.

\section{LANDASAN TEORI}

Shopping Mall merupakan pusat perbelanjaan yang secara arsitektur berupa bangunan tertutup yang terdiri dari beberapa department store dan kafe dengan desain unik. User (pengunjung Shopping Mall) yang sangat banyak, sehingga memiliki sistem keamanan tersendiri. Mengetahui posisi user pada area Shopping Mall melalui aplikasi android merupakan teknologi baru yang dapat membantu meningkatkan sistem keamanan yang telah ada.

\section{A. Indoor Positioning System (IPS)}

Global Positioning System (GPS) merupakan sebuah sistem yang dapat menghitung dan menentukan posisi seseorang di permukaan bumi secara akurat dalam bentuk representasi latitude dan longitude. Akan tetapi sinyal GPS sangat sulit untuk menentukan posisi seseorang di dalam gedung terutama gedung bertingkat.

Indoor Positioning System (IPS) merupakan suatu sistem yang dapat menentukan posisi seseorang di dalam gedung. Sistem ini juga dapat menentukan orientasi dan arah pergerakan seseorang[3]. Implementasi IPS dapat dilakukan menggunakan bermacam-macam pendekatan, umumnya menggunakan peralatan tambahan seperti sensor ultrasonic, sensor infrared, RFID dan beberapa peralatan lainnya. Dalam penentuan posisi dapat dilakukan pendekatan optis menggunakan LED[4] maupun pemanfaatan sinyal Wi-Fi[5]. Received Signal Strength Indication (RSSI) merupakan pengukuran terhadap daya sinyal radio yang diterima oleh receiver yang dikirim oleh transmitter. Nilai RSSI dapat ditemukan pada teknologi WLAN atau Wi-Fi untuk menentukan posisi. Nilai RSSI yang diterima oleh antena penerima menunjukkan kuat daya sinyal yang dinyatakan dalam dB(desibel)[6]. Pembacaan nilai RSSI dapat menggunakan aplikasi pendukung pihak ketiga yang dikembangkan di sistem operasi yang berjalan di smartphone.

Ceylan dkk, mengatakan bahwa tidak ada aturan mengenai persamaan untuk menghitung RSSI. Setiap

$$
\operatorname{RSSI}=-\left(10 \cdot n \cdot \log _{10} \mathrm{~d}+\mathrm{A}\right)
$$

dengan

$$
\begin{aligned}
\mathrm{n}= & \text { nilai path loss exponent }(\mathrm{db}) \\
\mathrm{d}= & \text { nilai jarak antara receiver } \mathrm{dan} \\
& \text { transmitter }(\mathrm{m}) \\
\mathrm{A}= & \text { kekuatan sinyal yang diterima } \\
& \text { pada jarak } 1 \text { meter }(\mathrm{dbm})
\end{aligned}
$$

Dari persamaan di atas dapat dihitung jarak dari receiver dari transmitter dengan Persamaan 2.2

$$
\mathrm{d}=\frac{\mathrm{RSSI}+\mathrm{A}}{-10 . \mathrm{n}}
$$

Path loss exponent merupakan parameter $\mathrm{n}$ yang sangat berpengaruh dalam menentukan batas kritis dari cakupan wilayah. Parameter tersebut dapat dicari berdasarkan pada data pengukuran yang tergantung dari kondisi lingkungan sekitar.

\section{B. QR Code}

Sebuah kode batang (barcode) adalah suatu kumpulan data optik yang dibaca mesin. Barcode ini mengumpulkan data dalam lebar (garis) dan spasi garis paralel dan dapat disebut sebagai kode batang atau simbologi linier atau 1D (1 dimensi), tapi juga memilki bentuk persegi, titik, heksagon dan bentuk geometri lainnya di dalam Gambar yang disebut kode matriks atau simbol 2D (2 dimensi)[18]. Contoh barcode 2 dimensi dapat dilihat pada Gambar 2.1 dengan tulisan "Jurusan Sistem Komputer Universitas Andalas Padang”.

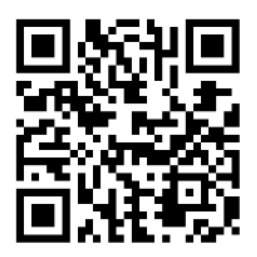

\section{Gambar 2.1 Contoh QR Code [9]}

QR Code merupakan singkatan dari Quick Response Code yang dikembangkan oleh Denso Corporation, sebuah perusahaan Jepang yang bergerak di bidang otomotif. QR Code merupakan image berupa matriks dua dimensi yang memiliki kemampuan untuk menyimpan data di dalamnya. QR Code merupakan evolusi dari kode batang (barcode)[10]. Informasi yang dikodekan dalam QR Code dapat berupa URL, nomor telepon, pesan SMS, V-Card, atau teks apapun[11].

\section{Aplikasi Mobile}

Aplikasi mobile adalah proses pengembangan aplikasi untuk perangkat genggam seperti PDA, asistem digital perusahaan atau telepon genggam. Aplikasi ini sudah ada pada telepon selama manufaktur, atau dapat diunduh oleh pelanggan dari toko aplikasi dan dari distribusi perangkat lunak mobile platform yang lain.

\section{Firebase}

Firebase adalah layanan yang memungkinkan pengembang membuat API untuk disinkronisasikan untuk client yang 
berbeda-beda dan disimpan pada cloud Firebase. Firebase memiliki banyak library yang memunggkinkan untuk mengintegrasikan layanan ini dengan Android, IOS, Javascript, Java, Objective-C dan Node.JS[12].

\section{METODE PENELITIAN}

\section{A. Jenis Penelitian}

Jenis penelitian yang digunakan dalam pembuatan tugas akhir ini adalah penelitian eksperimental (Experimental Research). Dalam penelitian ini dilakukan perancangan sistem yang nantinya dapat memonitoring posisi user menggunakan QR Code sebagai user identifier (UID) yang terhubung pada Wi-Fi yang tersedia di area Shopping Mall.

Penelitian ini ditunjang dengan studi literatur (literatur research), yaitu dengan membaca dan mempelajari literatur tentang perancangan monitoring posisi objek dalam gedung bertingkat. Pada penelitian ini perancangan monitoring posisi objek dilakukan menggunakan aplikasi Smartphone android. Gambar 3.1 merupakan rancangan umum dari penelitian yang akan dibuat:

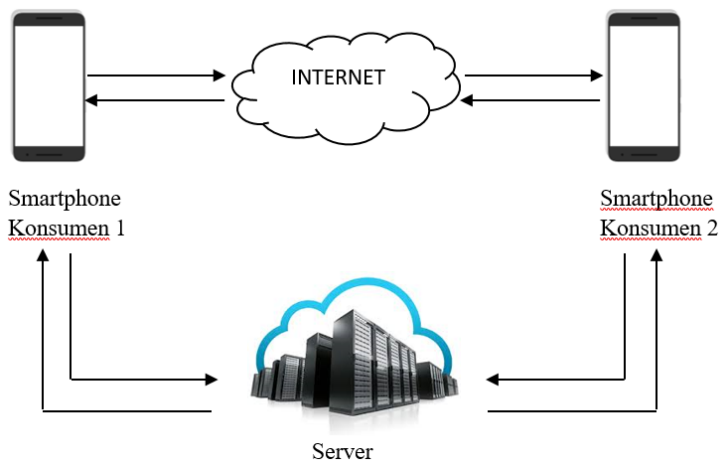

Gambar 3.1. Arsitektur Rancangan Umum Sistem

Berdasarkan Gambar 3.1 rancangan umum sistem adalah setiap user memiliki smartphone android yang memiliki aplikasi Indoor Positioning System. Langkah pertama untuk melakukan monitoring posisi user adalah melakukan penginputan data user sehingga data tersebut dapat disimpan dalam database. Setiap user yang telah menginputkan data akan mendapatkan QR Code sebagai user id. Selanjutnya user tersebut dapat menambahkan user lainnya sebagai teman yang dapat dimonitoring posisinya.

\section{B. Rancangan Hardware}

Sistem monitoring ini menggunakan Smartphone android dan server untuk dapat bekerja dengan baik. Perancangan hardware dari sistem ini adalah sebagai berikut:

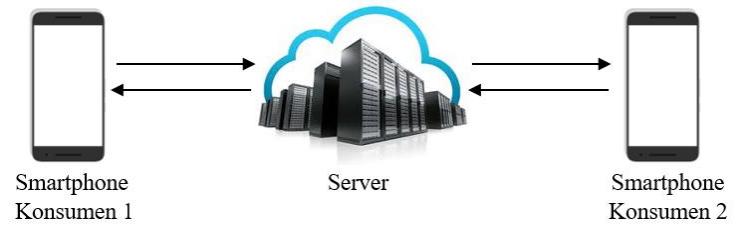

Gambar 3.3. Perancangan Hardware

Berdasarkan Gambar 3.3., prinsip kerja dari sistem ini adalah:
1. Pada smartphone terlebih dahulu telah terinstal aplikasi Indoor Positioning System. Kamera pada smartphone digunakan sebagai pembaca QR Code untuk mendapatkan UID.

2. Server digunakan sebagai penyimpanan data user.

\section{Rancangan Software}

Berikut merupakan rancangan proses yang akan dilakukan sebagai berikut.

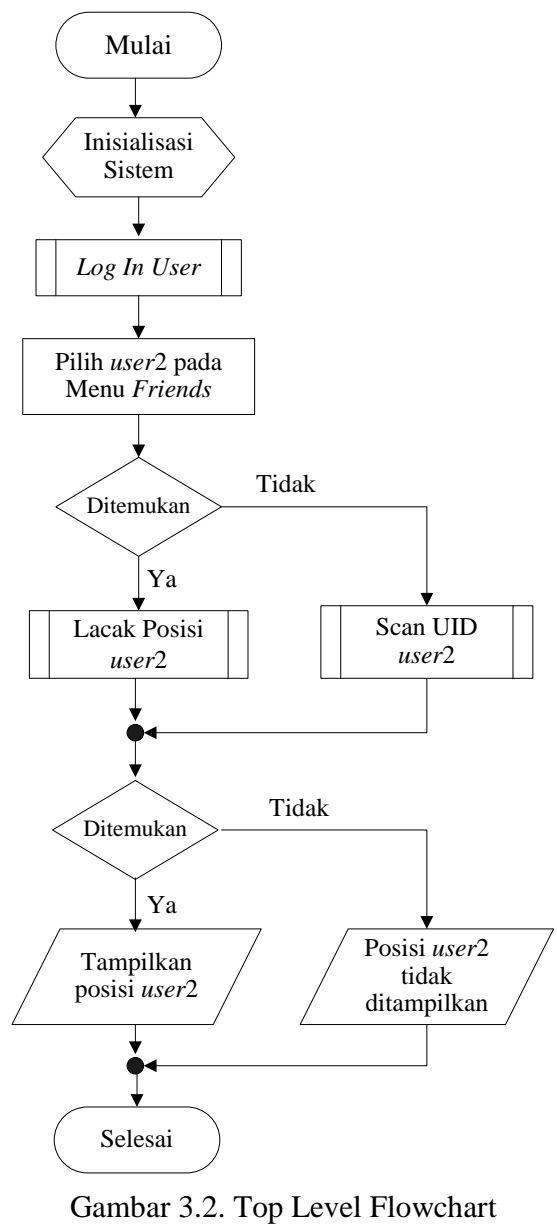

Berdasarkan flowchart di atas, setelah dilakukan inisialisasi pada sistem maka akan dilakukan proses log in oleh user ke aplikasi. Selanjutnya pilih user2 yang akan dimonitoring posisinya pada menu teman, apabila user 2 belum terdaftar pada menu teman maka lakukan penambahan teman dengan melakukan scan UID user2. Kemudian proses melacak posisi user 2 dapat dilakukan dan diketahui posisinya.

\section{RESULTS AND DISCUSSION}

A. Implementasi Perangkat Keras

Pada implementasi perangkat keras (hardware) terdapat laptop yang berfungsi sebagai server dari sistem, smartphone android yang berfungsi sebagai media untuk instalasi software dari sistem, kamera smartphone yang berfungsi sebagai pembaca UID dalam bentuk QR Code, dan router yang berfungsi untuk dapat memancarkan sinyal Wi-Fi. 


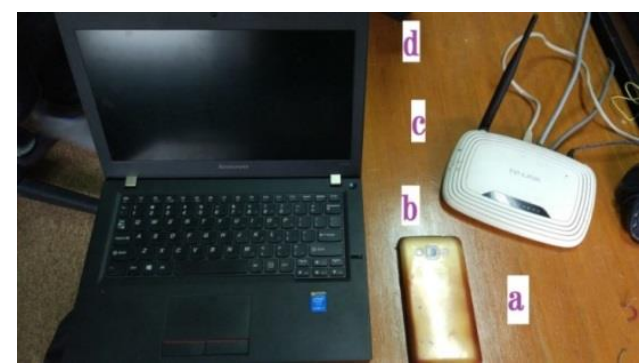

Gambar 4.1. Implementasi Perangkat Keras

Pada Gambar 4.1. terdapat beberapa komponen yang digunakan sebagai implementasi perangkat keras (hardware) :

a. Smartphone Android : berfungsi sebagai media instalasi software dari sistem

b. Kamera Smartphone : berfungsi sebagai media untuk melakukan pembacaan UID dalam bentuk QR Code

c. Router : berfungsi untuk memancarkan sinyal Wi-Fi yang dapat ditangkap oleh smartphone user

d. Laptop : berfungsi untuk mengakses cloud server

B. Implementasi Perangkat Lunak

Pada implementasi perangkat lunak (software) terdapat aplikasi mobile dengan pembangun aplikasi menggunakan software Android Studio.

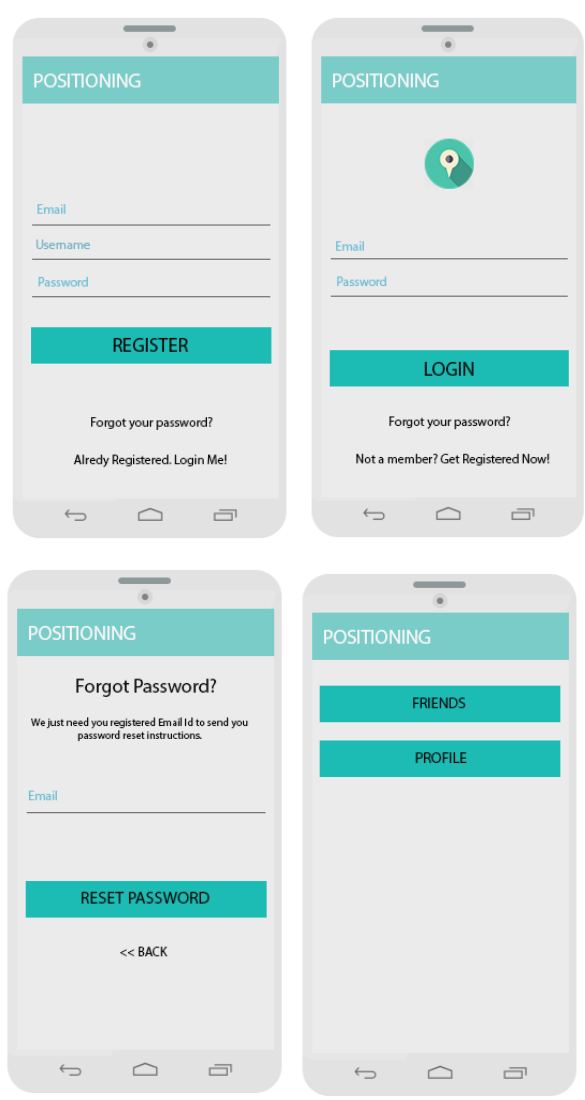

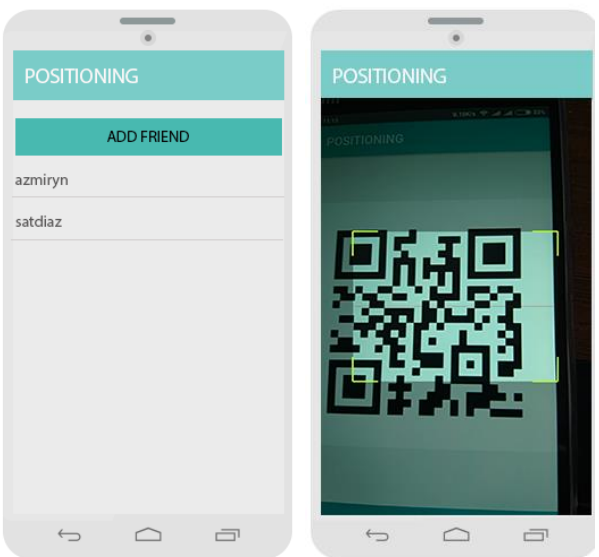
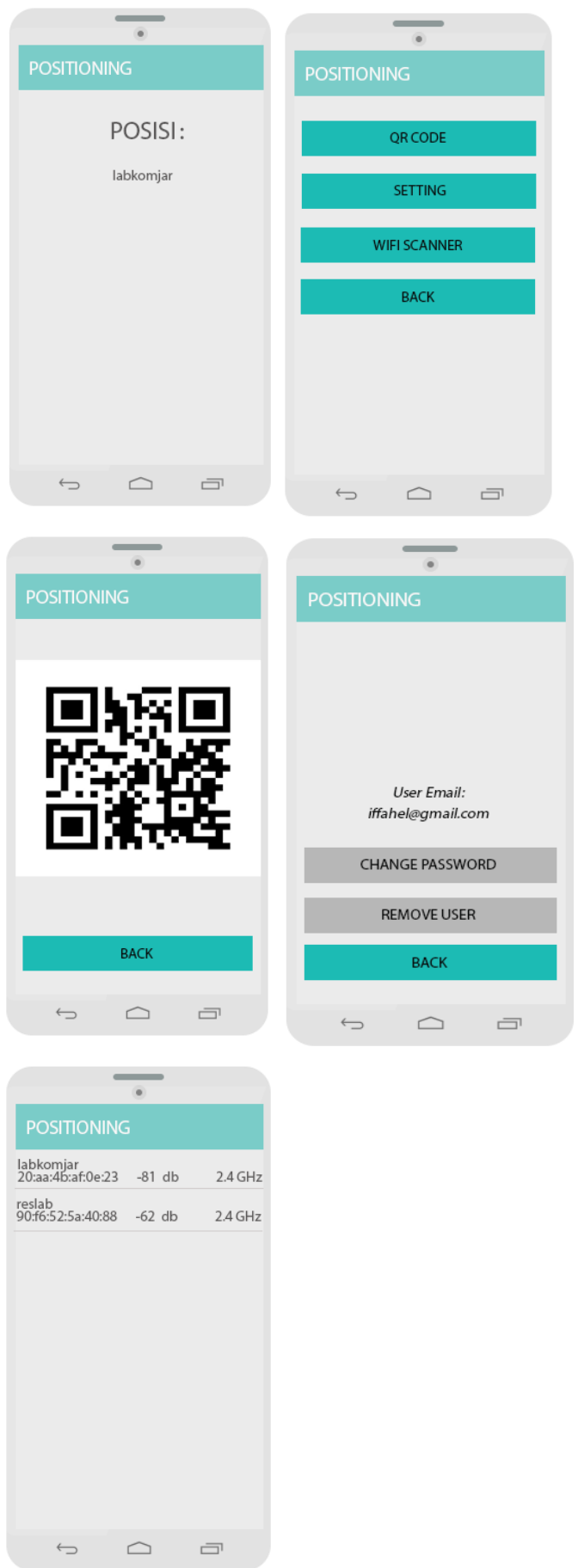
Pada sistem monitoring posisi user pada area Shopping Mall hanya menggunakan 1 buah aplikasi mobile, yakni aplikasi yang dapat digunakan oleh user. Aplikasi ini akan menampilkan halaman login user, halaman daftar user2(halaman Friends), halaman untuk mengetahui posisi user2, dan halaman untuk melakukan pembacaan UID yaitu halaman scanning. Pada aplikasi mobile ini user terlebih dahulu telah terdaftar pada server untuk mendapatkan data user.

C. Pengujian Halaman Posisi

Pengujian dilakukan pada gedung Transmart Padang Lantai 1 dengan denah gedung seperti pada Gambar 4.18.

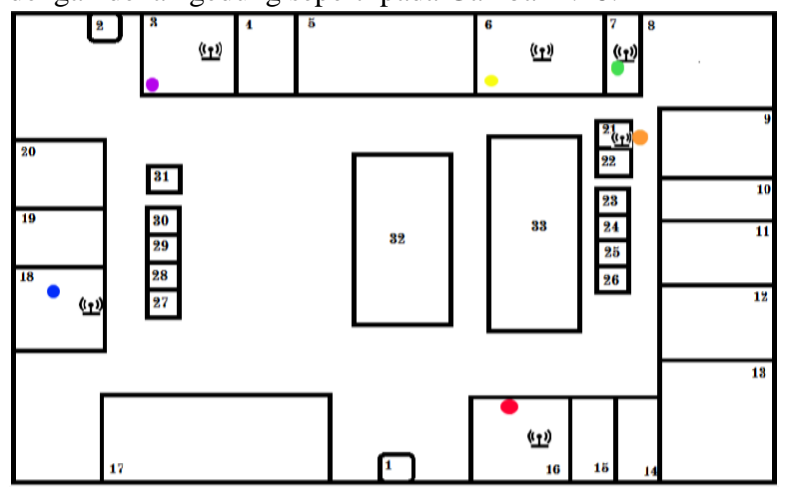

Gambar 4.18. Denah Gedung Transmart Padang Lantai 1

Pada Gambar 4.18 terdapat beberapa toko yang ada pada denah Gedung Transmart Padang Lantai 1 sebagai berikut:
1. Pintu Masuk Depan
17. Wendys
2. Pintu Masuk Belakang
18. Ichiban Sushi
3. Marcoffee Bistro
19. Sop Buntut
4. Soto Garuda
5. Solaria
21. Dum Dum Thai Tea
6. Optik Melawai
22. Lolie Crepes
7. Kkuldak
23. Monsta Eyescream
8. ATM
24. Angkringan Kids
9. Iko Gantinyo
10. Hoya Bakery
25. Mrs. Mango
26. Mrs. Waffle
11. Ayam Geprek Cobek
27. Think Thai
12. Imperial Kitchen
28. Sour Sally Mini
13. Kios K
29. Lapak Kosong
14. Bank Mega
30. Kopmil Omping
15. Baskin Robbin
31. Mandys
16. The Coffee Bean
32. Escalator

20. Bakso Lapangan Tembak

Hasil pengujian halaman posisi dapat dilihat pada Tabel 4.3.
Tabel 4.3 Pengujian Halaman Posisi pada Gedung Transmart Padang Lantai 1

\begin{tabular}{|c|l|l|l|c|c|}
\hline No & Warna & Username & \multicolumn{1}{|c|}{ Posisi } & RSSI & Posistioning \\
\hline 1 & & Diaz & @ marcoffeeb & -69 & Berhasil \\
& & & istro.pdg & $\mathrm{db}$ & \\
\hline 2 & & Danu & OPTIK & -57 & Berhasil \\
& & & MALAWAI & $\mathrm{db}$ & \\
\hline 3 & & Azmiryn & KKULDAK & -55 & Berhasil \\
& & & & $\mathrm{db}$ & \\
\hline 4 & & Maman & DUM DUM & -54 & Berhasil \\
& & & THAI & $\mathrm{db}$ & \\
& & & DRINKS & & \\
\hline 5 & & bayu & coffeebean@ & -57 & Berhasil \\
& & ramadeza & Wi-Fi.id & $\mathrm{db}$ & \\
\hline 6 & & Fitri & ICHIBAN_S & -48 & Berhasil \\
& & & USHI_ & $\mathrm{db}$ & \\
& & & PADANG & & \\
\hline
\end{tabular}

Perhitungan jarak transmitter dilakukan menggunakan nilai RSSI yang didapatkan oleh sistem. Perhitungan ini dilakukan untuk mengetahui jara antara Wi-Fi sebagai pemancar sinyal dengan smartphone user yang digunakan sebagai penerima sinyal. berikut adalah data perhitungan jarak transmitter dan perhitungan alas pada Tabel 4.4:

\begin{tabular}{|c|l|c|c|c|c|c|c|}
\hline No & \multicolumn{1}{|c|}{ Posisi } & $\begin{array}{c}\text { RSSI } \\
(\mathrm{sistem})\end{array}$ & $\begin{array}{c}\mathrm{n} \\
(\mathrm{db})\end{array}$ & $\begin{array}{c}\text { A } \\
(\mathrm{dbm})\end{array}$ & $\begin{array}{c}\text { Tinggi } \\
(\mathrm{m})\end{array}$ & $\begin{array}{c}\mathrm{D} \\
(\mathrm{m})\end{array}$ & $\begin{array}{c}\text { alas } \\
(\mathrm{m})\end{array}$ \\
\hline 1 & $\begin{array}{l}\text { Marcoffee } \\
\text { Bistro }\end{array}$ & $-69 \mathrm{dbm}$ & 1,6 & -56 & 3 & 7,8 & 7,2 \\
\hline 2 & $\begin{array}{l}\text { Optik } \\
\text { Malawai }\end{array}$ & $-57 \mathrm{dbm}$ & 1,6 & -36 & 3 & 5,8 & 4,9 \\
\hline 3 & Kkuldak & $-55 \mathrm{dbm}$ & 1,6 & -35 & 3 & 5,6 & 4,7 \\
\hline 4 & $\begin{array}{l}\text { Dum Dum } \\
\text { Thai Tea }\end{array}$ & $-54 \mathrm{dbm}$ & 2,2 & -51 & 4 & 4,8 & 2,7 \\
\hline 5 & $\begin{array}{l}\text { The Coffee } \\
\text { Bean }\end{array}$ & $-57 \mathrm{dbm}$ & 1,8 & -45 & 2,5 & 5,7 & 5,1 \\
\hline 6 & $\begin{array}{l}\text { Ichiban } \\
\text { Sushi }\end{array}$ & $-48 \mathrm{dbm}$ & 1,6 & -35 & 3 & 5,2 & 4,2 \\
\hline
\end{tabular}

Perbandingan data nilai RSSI ini dilakukan dengan membandingkan data dari nilai RSSI yang didapat oleh sistem dengan nilai RSSI yang didapat secara perhitungan manual.

\begin{tabular}{|c|c|c|c|}
\hline No & RSSI (sistem) & $\begin{array}{c}\text { RSSI } \\
\text { (manual) }\end{array}$ & $\begin{array}{c}\text { Error } \\
(\%)\end{array}$ \\
\hline 1 & $-69 \mathrm{dbm}$ & $-68,8 \mathrm{dbm}$ & 0,29 \\
\hline 2 & $-57 \mathrm{dbm}$ & $-57,28 \mathrm{dbm}$ & 0,49 \\
\hline 3 & $-55 \mathrm{dbm}$ & $-54,28 \mathrm{dbm}$ & 1,33 \\
\hline 4 & $-54 \mathrm{dbm}$ & $-52,84 \mathrm{dbm}$ & 2,19 \\
\hline 5 & $-57 \mathrm{dbm}$ & $-57,6 \mathrm{dbm}$ & 1,04 \\
\hline 6 & $-48 \mathrm{dbm}$ & $-47,56 \mathrm{dbm}$ & 0,93 \\
\hline
\end{tabular}

Pengujian kedua dilakukan pada Gedung Jurusan Sistem Komputer Universitas Andalas Lantai 2, seperti pada Gambar 4.19.

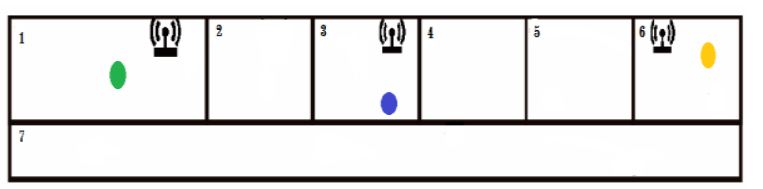


Gambar.4.19. Denah Gedung Jurusan Sistem Komputer Universitas Andalas Lantai 2

Pada Gambar 4.19 terdapat beberapa ruangan yang ada pada denah Gedung Jurusan Sistem Komputer Lantai 2 sebagai berikut.

1. Robotics and Embedded System Laboratory

2. Jurusan Sistem Komputer

3. Laboratorium Pemograman

4. Laboratorium Pengolahan Sinyal

5. Laboratorium Sistem Digital dan Aarsitektur Komputer

6. Himpunan Mahasiswa Sistem Komputer

7. Koridor Jurusan Sistem Komputer

Hasil pengujian halaman posisi dapat dilihat pada Tabel 4.3.

\begin{tabular}{|c|c|c|l|c|c|}
\hline No & Warna & $\begin{array}{c}\text { User } \\
\text { name }\end{array}$ & Posisi & RSSI & Posistioning \\
\hline 1 & $\bigcirc$ & Diaz & RESLab & -53 & Berhasil \\
& & & & $\mathrm{db}$ & \\
\hline 2 & & Danu & Labkomjar & -54 & Berhasil \\
& & & & $\mathrm{db}$ & \\
\hline 3 & $\bigcirc$ & Azm & HMSK & -52 & Berhasil \\
& & & $\mathrm{db}$ & \\
\hline
\end{tabular}

Perhitungan jarak transmitter dilakukan menggunakan nilai RSSI yang didapatkan oleh sistem. Perhitungan jarak transmitter dari posisi user ke posisi Wi-Fi dengan kondisi Wi-Fi tidak terhubung oleh client dari nilai RSSI yang didapatkan oleh sistem, berikut adalah data perhitungan jarak transmitter pada Tabel 4.4:

\begin{tabular}{|c|l|c|c|c|c|}
\hline No & \multicolumn{1}{|c|}{ Posisi } & $\begin{array}{c}\text { RSSI } \\
(\text { sistem })\end{array}$ & $\begin{array}{c}\mathrm{n} \\
(\mathrm{db})\end{array}$ & $\begin{array}{c}\mathrm{A} \\
(\mathrm{dbm})\end{array}$ & $\begin{array}{c}\mathrm{d} \\
(\mathrm{m})\end{array}$ \\
\hline 1 & $\begin{array}{l}\text { Robotics and } \\
\text { Embedded } \\
\text { System } \\
\text { Laboratory }\end{array}$ & $-53 \mathrm{dbm}$ & 1,6 & -34 & 5,4 \\
\hline 2 & $\begin{array}{l}\text { Laboratorium } \\
\text { Komputer dan } \\
\text { Jaringan }\end{array}$ & $-54 \mathrm{dbm}$ & 1,6 & -34 & 5,5 \\
\hline 3 & $\begin{array}{l}\text { Himpunan } \\
\text { Mahasiswa } \\
\text { Sistem } \\
\text { Komputer }\end{array}$ & $-52 \mathrm{dbm}$ & 1,6 & -34 & 5,4 \\
\hline
\end{tabular}

Perhitungan jarak transmitter dari posisi user ke posisi $W i-F i$ dengan kondisi $\mathrm{Wi}-\mathrm{Fi}$ terhubung oleh client dari nilai RSSI yang didapatkan oleh sistem, berikut adalah data perhitungan jarak transmitter pada Tabel 4.4 .

\begin{tabular}{|c|l|c|c|c|c|c|}
\hline No & \multicolumn{1}{|c|}{ Posisi } & $\begin{array}{c}\text { RSSI } \\
(\mathrm{sistem})\end{array}$ & $\begin{array}{c}\mathrm{N} \\
(\mathrm{db})\end{array}$ & $\begin{array}{c}\mathrm{A} \\
(\mathrm{dbm})\end{array}$ & $\begin{array}{c}\mathrm{d} \\
(\mathrm{m})\end{array}$ & $\begin{array}{l}\text { Client } \\
\text { terhubung }\end{array}$ \\
\hline 1 & $\begin{array}{l}\text { Robotics and } \\
\text { Embedded } \\
\text { System } \\
\text { Laboratory }\end{array}$ & $-62 \mathrm{dbm}$ & 1,6 & -34 & 6 & 8 \\
\hline 2 & $\begin{array}{l}\text { Laboratorium } \\
\text { Komputer dan } \\
\text { Jaringan }\end{array}$ & $-64 \mathrm{dbm}$ & 1,6 & -34 & 6,1 & 11 \\
\hline 3 & $\begin{array}{l}\text { Himpunan } \\
\text { Mahasiswa } \\
\text { Sistem } \\
\text { Komputer }\end{array}$ & $-54 \mathrm{dbm}$ & 1,6 & -34 & 5,5 & 2 \\
\hline
\end{tabular}

Perbandingan perhitungan nilai RSSI manual dan nilai RSSI yang didapatkan oleh sistem dengan kondisi Wi-Fi tidak terhubung oleh client, berikut adalah seluruh perbandingan perhitungan nilai RSSI pada dari semua percobaan posisi pada Tabel 4.9.

\begin{tabular}{|c|c|c|c|}
\hline No & $\begin{array}{c}\text { RSSI } \\
\text { (sistem) }\end{array}$ & $\begin{array}{c}\text { RSSI } \\
\text { (manual) }\end{array}$ & $\begin{array}{c}\text { Error } \\
(\%)\end{array}$ \\
\hline 1 & $-53 \mathrm{dbm}$ & $-53,2 \mathrm{dbm}$ & 0,38 \\
\hline 2 & $-54 \mathrm{dbm}$ & $-55,6 \mathrm{dbm}$ & 2,88 \\
\hline 3 & $-52 \mathrm{dbm}$ & $-51,6 \mathrm{dbm}$ & 0,78 \\
\hline
\end{tabular}

Perbandingan perhitungan nilai RSSI manual dan nilai RSSI yang didapatkan oleh sistem dengan kondisi Wi-Fi terhubung oleh client, berikut adalah seluruh perbandingan perhitungan nilai RSSI pada dari semua percobaan posisi pada Tabel 4.9:

\begin{tabular}{|c|c|c|c|}
\hline No & $\begin{array}{c}\text { RSSI } \\
(\text { sistem })\end{array}$ & $\begin{array}{c}\text { RSSI } \\
(\text { manual })\end{array}$ & $\begin{array}{c}\text { Error } \\
(\%)\end{array}$ \\
\hline 1 & $-62 \mathrm{dbm}$ & $-53,2 \mathrm{dbm}$ & 16,5 \\
\hline 2 & $-64 \mathrm{dbm}$ & $-55,6 \mathrm{dbm}$ & 15,1 \\
\hline 3 & $-54 \mathrm{dbm}$ & $-51,6 \mathrm{dbm}$ & 4,7 \\
\hline
\end{tabular}

Pada pengujian perhitungan nilai RSSI dan penentuan posisi yang dilakukan oleh sistem pada gedung Trnasmart Padang lantai 1 terlihat bahwa rata-rata persentase error yang sebenarnya yaitu $1,05 \%$, pada gedung Jurusan Sistem Komputer Universitas Andalas lantai 2 memiliki nilai rata-rata persentase error yang sebenarnya yaitu $1,35 \%$ dengan kondisi $W i-F i$ tidak tehubung oleh client, dan $12,1 \%$ dengan kondisi Wi-Fi terhubung dengan client. Rata-rata persentase error dari posisi pengujian secara keseluruhan yakni 4,9\%. Data yang didapat dapat disimpulkan keberhasilan posisi secara keselurahan yakni $100 \%$ yang menunjukan bahwa aplikasi dapat memonitoring posisi user dengan baik.

\section{KESIMPULAN}

Berdasarkan perancangan, pengamatan dan pengujian yang telah dilakukan maka dapat diambil kesimpulan sebagai berikut :

1. Sistem dapat melakukan scanning QR Code yang telah didaftarkan menjadi user identifier dengan persentase tingkat keberhasilan $100 \%$.

2. Sistem dapat melakukan monitoring posisi user di area Shopping Mall menggunakan sistem Indoor Positioning System (IPS) dengan persentase keberhasilan $100 \%$ berdasarkan persentase rata-rata keberhasilan seluruh pengujian sistem.

Sistem dapat menampilkan posisi user menggunakan aplikasi android dengan persentase tingkat keberhasilan $100 \%$ berdasarkan persentase rata-rata keberhasilan pengujian pada Gedung Transmart Padang Lantai 1 dan Gedung Jurusan Sistem Komputer. 


\section{SARAN}

Mengingat masih terdapat kekurangan dalam penelitian ini, maka perlu dilakukan beberapa perbaikan untuk memperbaiki kinerja sistem, adapaun beberapa saran yang diperlukan antara lain.

1. Untuk penelitian selanjutnya diharapkan sistem dapat menggunakan fitur map dari lokasi gedung untuk melakukan proses monitoring posis user.

\section{REFERENSI}

[1] Yahya, Nurul Nadia BT. 2010. "Monitoring Children in the Shopping Mall using RFID TechnologyControlling Module”. Malaysia: Universiti Malaysia Pahang.

[2] Musthafa, Alifia Ridho, dkk. 2016. "Sistem Navigasi Indoor Menggunakan Sinyal Wi-Fi dan Kompas Digital Berbasis Integrasi dengan Smartphone untuk Studi Kasus paa Gedung Bertingkat". J.Teknik ITS, vol. 5 , no. 2.

[3] A.Ghose, dkk. 2015. "Indoor Positioning System”, US Patent No. 14/450,890. 5 Feb 2015

[4] S. Y. Jung, S. "Optical Wireless Indoor Positioning System Using Light Emitting Diode Ceiling Lights", Microw. Opt. Technol. Lett., 54: 1622-1626. Doi: 10.1002/mop. 26880.

[5] N. Le-Dortz, N. dkk, "Wi-Fi Fingerprint Indoor Positioning System Using Probability Distribution Comparison", Prosiding ICASSP, 2012, p. 2301-2304.

[6] Santooso, Budi dkk. 2016. "Pengaruh Keberadaan Objek Manusia Terhadap Stabilitas Received Signal Strength Indicator (RSSI) pada Bluetooth Low Energy 4.0 (BLE). Telematika, Vol. 13, No. 01, JANUARI, 2016, Pp. 11-16

[7] Osman Ceylan, dkk. 2010. "Enhancing RSSI Technologies in Wireless Sensor Networks by Using Different Frequencies". In Proceedings of the 2010 International conference on Broadband, Wireless Computing, Communication and Application (pp. 369372). Washington, DC, USA

[8] Yudhanto, Yudha. 2003. "Sejarah Teknologi BARCODE", Ilmu Komputer.com

[9] Sumber : Data Penulis

[10] Rahayu, Yeni Dwi, dkk. 2006. "Pembuatan Aplikasi Pembacaan Quick Response Code Menggunakan Perangkat Mobile Berbasis J2ME Untuk Identifikasi Suatu Barang". Surabaya : Politeknik Elektronika Negri Surabaya Institut Teknologi Sepuluh Nopember [11] Ashford, Robin. 2010. "QR Code and Academic Libraries Eaching Mobile Users". (Online) http://crln.acrl.org/content/71/10/526.full

[12] Firebase, http://Firebase.google.com 